\title{
CALCIUM SILICATE AS SALT STRESS ATTENUATOR IN SEEDLINGS OF YELLOW PASSION FRUIT cv. BRS GA1 ${ }^{1}$
}

\author{
TARSO MORENO ALVES DE SOUZA², VANDER MENDONÇA², FRANCISCO VANIES DA SILVA SÁ ${ }^{2 *}$, \\ MEDSON JANER DA SILVA ${ }^{3}$, CAÍQUE SANTOS TOMÉ DOURADO ${ }^{4}$
}

\begin{abstract}
Salt stress causes losses in the yields of crops, especially those of great economic and socialfood importance, such as passion fruit. The objective of this study was to evaluate the effects of fertilization with calcium silicate on the mitigation of salt stress in yellow passion fruit seedlings. The experiment was conducted in a protected environment, in a randomized block design, arranged in a 4 × 3 factorial scheme, referring to four concentrations of calcium silicate $(0 ; 2.22 ; 4.44$ and $6.66 \mathrm{~g}$ per plant) and three levels of irrigation water salinity - $\mathrm{ECW}\left(0.5 ; 1.7\right.$ and $\left.4.0 \mathrm{dS} \mathrm{m} \mathrm{m}^{-1}\right)$, with four replicates, considering five plants as experimental unit. BRS GA1 seedlings were produced in $0.5-\mathrm{dm}^{3}$ containers filled with a mixture of soil, washed sand and aged bovine manure, in a ratio of 1:1:1 (v:v:v). Plants received calcium silicate applications according to the studied doses in three plots, at 30,45 and 60 days after sowing. At 90 days after sowing, plants were evaluated for growth and biomass accumulation. The use of water with salinity of $4.0 \mathrm{dS} \mathrm{m}^{-1}$ restricted the growth and biomass accumulation of passion fruit seedlings. The use of calcium silicate at dose of $3.5 \mathrm{~g}$ per plant mitigates salt stress in seedlings of passion fruit cultivar BRS GA1 when irrigated with saline water.
\end{abstract}

Keywords: Passiflora edulis. Salinity. Silicon. Biometrics. Biomass accumulation.

\section{SILICATO DE CÁLCIO COMO ATENUADOR DO ESTRESSE SALINO EM MUDAS DE MARACUJAZEIRO AMARELO cv. BRS GA1}

\begin{abstract}
RESUMO - O estresse salino ocasiona perda no rendimento das culturas, principalmente aquelas de grande importância econômica e socioalimentar, como o maracujazeiro. Com isso, objetivou-se nesta pesquisa avaliar os efeitos da adubação com silicato de cálcio na mitigação do estresse salino em mudas de maracujazeiro amarelo. O experimento foi conduzido em ambiente protegido, no delineamento experimental de blocos casualizados, arranjados em esquema fatorial 4 x 3 , referente a quatro concentrações de silicato de cálcio $(0$; 2,22; 4,44 e 6,66 g por planta) e três níveis de salinidade da água de irrigação - CEa $\left(0,5 ; 1,7\right.$ e $\left.4,0 \mathrm{dS} \mathrm{m}^{-1}\right)$, com quatro repetições, considerando como unidade experimental cinco plantas. As mudas da cultivar BRS GA1 foram produzidas em recipientes com capacidade para $0,5 \mathrm{dm}^{3}$, preenchidos com a mistura de solo, areia lavada e esterco bovino curtido, na proporção 1:1:1 (v:v). As plantas receberam aplicações de silicato de cálcio conforme as doses estudadas em três parcelas, aos 30, 45 e 60 dias após a semeadura. Aos 90 dias após a semeadura às plantas foram avaliadas quanto ao crescimento e acúmulo de biomassa. A utilização de água com salinidade de 4,0 dS m${ }^{-1}$ restringiu o crescimento e o acúmulo de biomassa das mudas de maracujazeiro. $\mathrm{O}$ uso de silicato de cálcio na dose de 3,5 g por planta mitiga o estresse salino em mudas de maracujazeiro cultivar BRS GA1 quando irrigadas com água salina.
\end{abstract}

Palavras-chave: Passiflora edulis. Salinidade. Silício. Biometria. Acúmulo de biomassa.

\footnotetext{
* Corresponding author

${ }^{1}$ Received for publication in $11 / 18 / 2019$; accepted in $02 / 19 / 2020$.

Paper extracted from the masters dissection of the first author.

${ }^{2}$ Center of Agrarian Sciences, Universidade Federal Rural do Semi-Árido, Mossoró, RN, Brazil; tarsomoreno.agro@gmail.com - ORCID: 0000-0003-2811-3245, vander@ufersa.edu.br - ORCID: 0000-0001-5682-5341, vanies_agronomia@hotmail.com - ORCID: 0000-0001$6585-8161$.

${ }^{3}$ Department of Human Sciences and Technologies, Universidade do Estado da Bahia, Xique-Xique, BA, Brazil; medsonjaner@hotmail.com - ORCID: 0000-0001-6155-3512.

${ }^{4}$ Faculdade Irecê, Irecê, BA, Brazil; caiquedouradojd@gmail.com - ORCID: 0000-0002-2023-0773.
} 


\section{INTRODUCTION}

Passion fruit (Passiflora edulis) is among the fruit crops with highest economic importance in Brazil, occupying a prominent position, even when compared to other tropical fruits with a greater tradition of consumption (MELETTI, 2011). However, passion fruit cultivation in the Brazilian semiarid region is under risk due to the problems of water and/or soil salinity in this region, since, according to Ayers and Westcot (1985), passion fruit is classified as sensitive to salinity, with threshold salinity of $1.3 \mathrm{dS} \mathrm{m}^{-1}$. For the electrical conductivity of irrigation water, passion fruit is affected from $2.1 \mathrm{dS} \mathrm{m}^{-1}$ (ARAÚJO et al., 2013).

Water salinity and soil salinity in arid and semiarid regions are the main obstacles to obtaining satisfactory production in the agricultural system (SÁ et al., 2018; 2020). This problem is related to changes in soil physical and chemical attributes, such as the action of specific ions on germination, growth, production and nutrition of plants (BEZERRA et al., 2016; SILVA et al., 2019; SÁ et al., 2020). These changes are intensified by the inadequate management of saline water in agriculture, contributing to the increase in the concentration of salts in the soil, especially sodium, hence increasing electrical conductivity and, gradually, the exchangeable sodium percentage (HOLANDA FILHO et al., 2011).

The effects of salinity on plants refer to changes in osmotic potential, as well as ionic, nutritional and hormonal imbalance, causing changes in the morphology, physiology and metabolism of plants, which lead to serious losses in the agricultural activity (OLIVEIRA et al., 2015; SÁ et al., 2017). Thus, the search for technologies that mitigate the effects of salinity must be constant, aiming at exploring irrigated areas with restrictions on salinity and/or the use of saline water in agriculture and at producing in an economically viable way, even in places with high contents of ions (SÁ et al., 2015).

Some studies have been conducted to mitigate the effects of salt stress on passion fruit plants, such as the use of different substrates (OLIVEIRA et al., 2015), nitrogen doses (BEZERRA et al., 2019) and exogenous application of hydrogen peroxide (SILVA et al., 2019). However, an effective method has not yet been defined to minimize the effects of salinity on passion fruit plants.

Among the alternatives to minimize the deleterious effects of salinity on plants, silicates such as calcium silicate $\left(\mathrm{CaSiO}_{3}\right)$ stand out, as they promote tolerance to water and/or salt stress conditions by guaranteeing the integrity and stability of the cell membrane (KAFI; RAHIMI, 2011;
MATEOS-NARANJO; ANDRADES-MORENO; DAVY, 2013; NEVES et al., 2019). Particularly when plants are grown in saline environments, silicon induces the reduction of the absorption of toxic ions, such as sodium $\left(\mathrm{Na}^{+}\right)$, and promotes the increase in potassium $\left(\mathrm{K}^{+}\right)$uptake (ASHRAF et al., 2010), which is attributed to its stimulating role of metabolic, physiological and structural activities of plants (SHEN et al., 2010; NEVES et al., 2019).

Thus, the use of silicates is an alternative to increase the capacity of plant species to survive through the effects of salinity. The objective of this study was to evaluate the effects of fertilization with calcium silicate on the mitigation of salt stress in yellow passion fruit seedlings.

\section{MATERIAL AND METHODS}

The experiment was installed at Fazenda Favela, located at $334 \mathrm{~km}$ of BA 052 Highway, in an area intended for seedling production, located in the municipality of João Dourado in the State of Bahia, Brazil (11 $\left.21^{\circ} \mathrm{S} ; 41^{\circ} 39^{\prime} 50^{\prime \prime} \mathrm{W}\right)$. The municipality is within the Polygon of Droughts and, according to Köppen's climatic classification, has warm and dry tropical climate (BSwh), typical of the northeastern semiarid region.

The experiment was conducted in a protected environment, in a randomized block design, arranged in a $4 \times 3$ factorial scheme, referring to four concentrations of calcium silicate $(0 ; 2.22 ; 4.44$ and $6.66 \mathrm{~g}$ per plant) and three levels of irrigation water salinity - ECw $\left(0.5 ; 1.7\right.$ and $\left.4.0 \mathrm{dS} \mathrm{m}^{-1}\right)$, with four replicates, considering five plants as experimental unit.

In the seedling formation phase, three seeds of the cultivar BRS GA1 were sown at $1 \mathrm{~cm}$ depth in each $0.5-\mathrm{dm}^{3}$ polyethylene bag. The substrate was composed of a mixture of ravine soil (Neossolo Flúvico - Entisol), washed sand and aged bovine manure, in the proportion 1:1:1 (v:v:v). The soil used in the experiment was chemically characterized for fertility before and after the application of treatments (Table 1).

After stabilization of emergence, at 30 days after sowing (DAS), thinning was performed, leaving only one plant per container. During this period, fertilization with calcium silicate began. Calcium silicate of analytically pure grade $\left(\mathrm{CaSiO}_{3}\right)$ has chemical characteristics of $22.00 \%$ calcium, $36.49 \%$ silicon and $41.51 \%$ oxygen. Calcium silicate was applied around the stem of plants (drench), with doses split into three portions, diluted in $50 \mathrm{~mL}$ of water and applied at 30, 45 and 60 days after sowing. 
T. M. A. SOUZA et al.

Table 1. Initial and final chemical characteristics of the substrate used.

\begin{tabular}{|c|c|c|c|c|c|c|c|c|c|c|c|c|}
\hline \multirow{2}{*}{ Samples } & $\mathrm{pH}$ & ECse & OM & $\mathrm{P}$ & $\mathrm{K}^{+}$ & $\mathrm{Na}^{+}$ & $\mathrm{Ca}^{2+}$ & $\mathrm{Mg}^{2+}$ & $\mathrm{H}^{+}+\mathrm{Al}^{3+}$ & $\mathrm{T}$ & $\mathrm{Si}$ & ESP \\
\hline & water & $\mathrm{dS} \mathrm{m}^{-1}$ & $\mathrm{~g} \mathrm{~kg}^{-1}$ & $\mathrm{mg} \mathrm{dm}^{-3}$ & \multicolumn{6}{|c|}{ 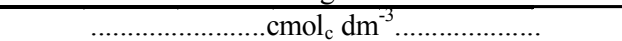 } & $\mathrm{mg} \mathrm{Kg}^{-1}$ & $\%$ \\
\hline ISS & 7.00 & 0.35 & 3.44 & 6.00 & 1.00 & 0.02 & 5.00 & 1.8 & 0.00 & 7.52 & 101.08 & 0.27 \\
\hline $\mathrm{S}_{1} \mathrm{Si}_{0}$ & 7.48 & 0.75 & 3.48 & 147.27 & 1.60 & 0.56 & 7.56 & 4.68 & 0.00 & 14.40 & 133.10 & 3.89 \\
\hline $\mathrm{S}_{2} \mathrm{Si}_{0}$ & 7.47 & 2.53 & 3.48 & 64.01 & 1.28 & 0.99 & 7.88 & 5.17 & 0.00 & 15.32 & 136.60 & 6.46 \\
\hline $\mathrm{S}_{3} \mathrm{Si}_{0}$ & 7.50 & 6.64 & 3.47 & 133.01 & 1.12 & 2.02 & 6.52 & 6.69 & 0.00 & 16.35 & 145.10 & 12.35 \\
\hline$\overline{\mathrm{S}_{1} \mathrm{Si}_{1}}$ & 7.41 & 0.85 & 3.48 & 85.11 & 1.44 & 0.82 & 7.67 & 5.97 & 0.00 & 15.9 & 153.90 & 5.16 \\
\hline $\mathrm{S}_{2} \mathrm{Si}_{1}$ & 7.35 & 2.72 & 3.46 & 98.79 & 1.18 & 1.25 & 8.37 & 6.73 & 0.00 & 17.53 & 172.80 & 7.13 \\
\hline $\mathrm{S}_{3} \mathrm{Si}_{1}$ & 7.42 & 6.81 & 3.48 & 59.44 & 1.44 & 2.62 & 7.57 & 6.43 & 0.00 & 18.06 & 148.70 & 14.51 \\
\hline $\mathrm{S}_{1} \mathrm{Si}_{2}$ & 7.53 & 0.81 & 9.23 & 70.28 & 1.23 & 0.73 & 9.05 & 5.27 & 0.00 & 16.28 & 125.15 & 4.48 \\
\hline $\mathrm{S}_{2} \mathrm{Si}_{2}$ & 7.47 & 2.62 & 9.21 & 139.28 & 1.28 & 0.91 & 8.59 & 5.24 & 0.00 & 16.02 & 191.80 & 5.68 \\
\hline $\mathrm{S}_{3} \mathrm{Si}_{2}$ & 7.49 & 6.51 & 9.27 & 80.54 & 0.80 & 1.50 & 7.28 & 5.54 & 0.00 & 15.12 & 139.10 & 9.92 \\
\hline $\mathrm{S}_{1} \mathrm{Si}_{3}$ & 7.62 & 0.87 & 7.21 & 57.73 & 0.96 & 0.73 & 7.18 & 5.25 & 0.00 & 14.12 & 132.10 & 5.17 \\
\hline $\mathrm{S}_{2} \mathrm{Si}_{3}$ & 7.45 & 2.45 & 8.81 & 92.52 & 0.75 & 0.65 & 7.05 & 6.09 & 0.00 & 14.54 & 161.05 & 4.47 \\
\hline $\mathrm{S}_{3} \mathrm{Si}_{3}$ & 7.49 & 6.69 & 6.05 & 73.13 & 1.23 & 2.10 & 8.04 & 5.51 & 0.00 & 16.88 & 169.40 & 12.44 \\
\hline
\end{tabular}

$\mathrm{P}, \mathrm{K}^{+}, \mathrm{Na}^{+}$: Mehlich 1 extractor; $\mathrm{Al}^{3+}, \mathrm{Ca}^{2+}, \mathrm{Mg}^{2+}: 1.0 \mathrm{~mol} \mathrm{~L}{ }^{-1} \mathrm{KCl}$ extractor; ECse: Electrical conductivity of the saturation extract; T: Cation exchange capacity; OM: Walkley-Black Wet Digestion; ESP: Exchangeable sodium percentage. ISS = initial sample of the substrate; $\mathrm{S}_{1}=0.5 ; \mathrm{S}_{2}=1.7$ and $\mathrm{S}_{3}=4.0 \mathrm{dS} \mathrm{m}{ }^{-1} . \mathrm{Si}_{0}=0 ; \mathrm{Si}_{1}=2.22 ; \mathrm{Si}_{2}=4.44$ and $\mathrm{Si}_{3}=6.66 \mathrm{~g} \mathrm{plant}^{-1}$.

Irrigations were carried out at 48-h intervals in order to leave the soil with moisture content close to its maximum retention capacity, determined based on the method of drainage lysimetry, and the water depth was applied along with a leaching fraction of 20\% (AYERS; WESTCOT, 1985). The volume applied (Va) per container was obtained by the difference between the previous water depth applied (Lp) minus the average drainage (D), divided by the number of containers (n) and multiplied by the leaching fraction (LF), as indicated in Equation 1:

$$
V a=\frac{L p-D}{n(1-L F)}
$$

Plants were irrigated with water of low electrical conductivity $\left(\mathrm{ECW}=0.5 \mathrm{dS} \mathrm{m}^{-1}\right)$, from the local supply system, during the first 30 DAS. From this period, the plants were irrigated according to the saline treatments. For the application of salinity levels, the water with $\mathrm{ECw}$ of $1.7 \mathrm{dS} \mathrm{m}^{-1}$ came from an artesian well, excavated in the locality of the experimental area. High-salinity water $(\mathrm{ECW}=$ $4.0 \mathrm{dS} \mathrm{m}^{-1}$ ) was obtained by adding sodium chloride $(\mathrm{NaCl})$ salts to the well water existing in the site $\left(\mathrm{ECW}=1.7 \mathrm{dS} \mathrm{m}^{-1}\right)$, as sodium and chloride make up $70 \%$ of salt ions found in sources of water used for irrigation in small farms in northeastern Brazil (MEDEIROS et al., 2003). This water was prepared considering the relationship between water electrical conductivity $(\mathrm{ECW})$ and salt concentration $\left(10 *\right.$ meq $\mathrm{L}^{-1}=1 \mathrm{dS} \mathrm{m}^{-1}$ of $\left.\mathrm{ECw}\right)$, as suggested by Rhoades et al. (1992), which is valid for $\mathrm{ECW}$ ranging from 0.1 to $5.0 \mathrm{dS} \mathrm{m} \mathrm{m}^{-1}$. The chemical analysis of water is shown in (Table 2). After preparing the waters with the respective levels of electrical conductivity, they were stored in $60-\mathrm{L}$ plastic containers, properly protected and identified with the respective levels of salinity, avoiding evaporation, entry of rainwater and contamination with materials that could compromise their quality.

Table 2. Chemical characterization of the waters used in the experiment.

\begin{tabular}{|c|c|c|c|c|c|c|c|c|c|}
\hline & \multicolumn{9}{|c|}{ Parameters } \\
\hline & $\mathrm{pH}$ & $\overline{\mathrm{EC}}$ & $\mathrm{K}^{+}$ & $\mathrm{Na}^{+}$ & $\mathrm{Mg}^{2+}$ & $\mathrm{Ca}^{2+}$ & $\mathrm{Cl}^{-}$ & $\mathrm{HCO}_{3}{ }^{-}$ & SAR \\
\hline & $\mathrm{H}_{2} \mathrm{O}$ & $\mathrm{dS} \mathrm{m}^{-1}$ & - & - n & $-1--n$ & 1 & - & ------- & $\left(\mathrm{mmol}_{\mathrm{c}} \mathrm{L}^{-1}\right)^{0.5}$ \\
\hline S1 & 7.37 & 0.50 & 0.31 & 2.79 & 1.20 & 0.83 & 1.90 & 3.30 & 1.96 \\
\hline S2 & 7.30 & 1.70 & 0.20 & 6.44 & 2.50 & 8.00 & 13.38 & 3.69 & 2.37 \\
\hline S3 & 7.17 & 4.00 & 0.20 & 29.35 & 2.50 & 8.00 & 36.33 & 3.69 & 10.07 \\
\hline
\end{tabular}

pH - Hydrogen potential; EC - Electrical conductivity; $\mathrm{K}^{+}$- Potassium; $\mathrm{Na}^{+}$- Sodium; $\mathrm{Mg}^{2+}$ - Magnesium; $\mathrm{Ca}^{2+}$ - Calcium; $\mathrm{Cl}^{-}$- Chlorine; $\mathrm{HCO}_{3}^{-}$- Bicarbonate; SAR - Sodium adsorption ratio.

Yellow passion fruit seedlings were irrigated with waters of the respective levels of salinity for 60 days. At 90 DAS, when the first tendrils appeared in $70 \%$ of the stand, the plants were analyzed for: height $(\mathrm{cm})$, measured with a ruler graduated in centimeters, from the collar to the apical meristem; stem diameter $(\mathrm{mm})$, determined with a caliper at the base of the collar at approximately $2 \mathrm{~cm}$ from the ground; number of leaves, obtained by counting all fully expanded leaves; leaf area $\left(\mathrm{cm}^{2}\right)$, estimated from the statistical model proposed by Schmildt et al. (2016), where $L A=0.5902 \times(C L L \times L W)$, with CLL being the central lobe length and LW being the largest leaf width, measured with a graduated ruler. 
To obtain shoot dry mass (SDM), root dry mass (RDM) and total dry mass (TDM) measured in $\mathrm{g}$, the substrate adhered to the root system was removed by washing with running water. Then, the roots and shoots of the plants were collected, dried in a forced air circulation oven at temperature of 65 ${ }^{\circ} \mathrm{C}$, until reaching constant masses, and weighed on a semi-analytical scale, with accuracy of $0.001 \mathrm{~g}$.

The results were subjected to analysis of variance by $\mathrm{F}$ test at $5 \%$ probability level. The means referring to calcium silicate doses were evaluated by polynomial regression analysis ( $\mathrm{p} \leq$ 0.05 ) and those referring to salinity were compared by Tukey means comparison test $(p \leq 0.05)$. When necessary, the data were transformed to square root. Data analysis was performed using the statistical software program SISVAR 5.6 (FERREIRA, 2014).

\section{RESULTS AND DISCUSSION}

The interaction between salinity levels and calcium silicate doses was significant $(p<0.01)$ for the variables plant height $(\mathrm{PH})$, stem diameter (SD), leaf area (LA), shoot dry mass (SDM), root dry mass (RDM) and total dry mass (TDM) (Table 3). For the number of leaves (NL), the interaction was significant at $5 \%$ probability level $(\mathrm{p}<0.05)$. These results indicate that fertilization with calcium silicate influenced the responses of yellow passion fruit irrigated with saline water in the seedling production phase.

Table 3. Summary of analysis of variance for plant height (PH), stem diameter (SD), number of leaves (NL), leaf area (LA), shoot dry mass (SDM), root dry mass (RDM) and total dry mass (TDM) of yellow passion fruit plants irrigated with saline water under different doses of calcium silicate.

\begin{tabular}{|c|c|c|c|c|c|c|c|c|}
\hline \multirow{2}{*}{ Source of variation } & \multicolumn{8}{|c|}{ Mean squares } \\
\hline & $\mathrm{DF}$ & $\mathrm{PH}^{1}$ & SD & $\mathrm{NL}$ & $\mathrm{LA}^{1}$ & $\mathrm{SDM}^{1}$ & $\mathrm{RDM}^{1}$ & $\mathrm{TDM}^{1}$ \\
\hline Block & 3 & $0.97^{*}$ & $0.55 * *$ & $0.71^{\mathrm{NS}}$ & $5.60^{*}$ & $0.17 * *$ & $0.148 * *$ & $0.27 * *$ \\
\hline Salinity (SAL) & 2 & $6.27 * *$ & $0.54 * *$ & $3.42 *$ & $31.28 * *$ & $0.27 * *$ & $0.098 * *$ & $0.36^{* *}$ \\
\hline $\mathrm{Si}$ doses $(\mathrm{Si})$ & 3 & $3.58 * *$ & $0.61 * *$ & $3.85^{*}$ & $20.95 * *$ & $0.21 * *$ & $0.034 * *$ & $0.22 * *$ \\
\hline $\mathrm{SAL} \times \mathrm{Si}$ & 6 & $2.49 * *$ & $0.37 * *$ & $1.82 *$ & $14.39 * *$ & $0.12 * *$ & $0.023 * *$ & $0.12 * *$ \\
\hline Error & 33 & 0.33 & 0.04 & 0.40 & 1.81 & 0.02 & 0.005 & 0.02 \\
\hline CV (\%) & & 13.72 & 7.54 & 7.83 & 9.48 & 12.14 & 9.21 & 10.72 \\
\hline Overall mean & & 4.24 & 2.66 & 8.11 & 14.23 & 1.28 & 0.79 & 1.51 \\
\hline
\end{tabular}

${ }^{* *}$ Significant at $1 \%$ probability level; *Significant at $5 \%$ probability level; ${ }^{\text {ns }}$ not significant by $\mathrm{F}$ test; ${ }^{1}$ data transformed to $\sqrt{X}$.

Plant height increased linearly with the increase in calcium silicate doses when yellow passion fruit plants cv. BRS GA1 were irrigated with low-salinity water $\left(\mathrm{S}_{1}=0.5 \mathrm{dS} \mathrm{m}^{-1}\right)$, with increments of $10.86 \mathrm{~cm}$ for each $1 \mathrm{~g}$ increase in the calcium silicate dose (Figure 1A). Similar behavior was observed for plants irrigated with water of intermediate salinity $\left(\mathrm{S}_{2}=1.7 \mathrm{dS} \quad \mathrm{m}^{-1}\right)$, which responded linearly to the increase in the silicon dose, with increments of $5.77 \mathrm{~cm}$ for each gram added to the substrate (Figure 2A). The increase in water salinity from 0.5 to $1.7 \mathrm{dS} \mathrm{m}^{-1}$, despite not restricting plant growth, reduced the response of growth in height by $46.86 \%$ to the unit increment of $\mathrm{Si}$ doses (Figure 1A).

In yellow passion fruit seedlings irrigated with $4.0 \mathrm{dS} \mathrm{m}^{-1}$ water, plant height was increased by up to $15.8 \mathrm{~cm}$ at the estimated $\mathrm{CaSiO}_{3}$ dose of $2.82 \mathrm{~g}$ plant $^{-1}$. It is important to highlight that silicate fertilization attenuated salt stress in passion fruit seedlings irrigated with high-salinity water, which obtained heights similar to those of seedlings irrigated with low-salinity water, in the absence of fertilization with calcium silicate (Figure 1A).
The stem diameter of seedlings irrigated with low-salinity water $\left(\mathrm{S}_{1}=0.5 \mathrm{dS} \mathrm{m}^{-1}\right)$ responded linearly to the calcium silicate doses, with increments of $0.39 \mathrm{~mm}$ for each $1 \mathrm{~g}$ increase in the calcium silicate dose, which corresponded to a $41 \%$ increase in plants fertilized with $6.66 \mathrm{~g}$ of $\mathrm{CaSiO}_{3}$ plant $^{-1}$, compared to the zero dose (Figure 2B). However, there was no significant fit of calcium silicate doses for the stem diameter of seedlings irrigated with water of intermediate salinity $\left(\mathrm{S}_{2}=1.7\right.$ $\left.\mathrm{dS} \mathrm{m}^{-1}\right)$, with an average diameter of $2.65 \mathrm{~mm}$ (Figure 2B). In seedlings irrigated with high-salinity water $\left(\mathrm{S}_{2}=4.0 \mathrm{dS} \mathrm{m} \mathrm{m}^{-1}\right)$, the behavior of growth in diameter was quadratic, with the largest diameter of $2.74 \mathrm{~mm}$, obtained with the maximum estimated dose of $3.63 \mathrm{~g}$ of calcium silicate per plant. It is also observed that fertilization with up to $6.66 \mathrm{~g}$ of calcium silicate led to a stem diameter larger than those obtained at the zero dose, at the highest salinity. In addition, fertilization with up to $4.44 \mathrm{~g}$ of $\mathrm{CaSiO}_{3}$ plant $^{-1}$ maintained the stem diameter with a size similar to those of seedlings irrigated with lowand intermediate-salinity water (Figure 2B). 

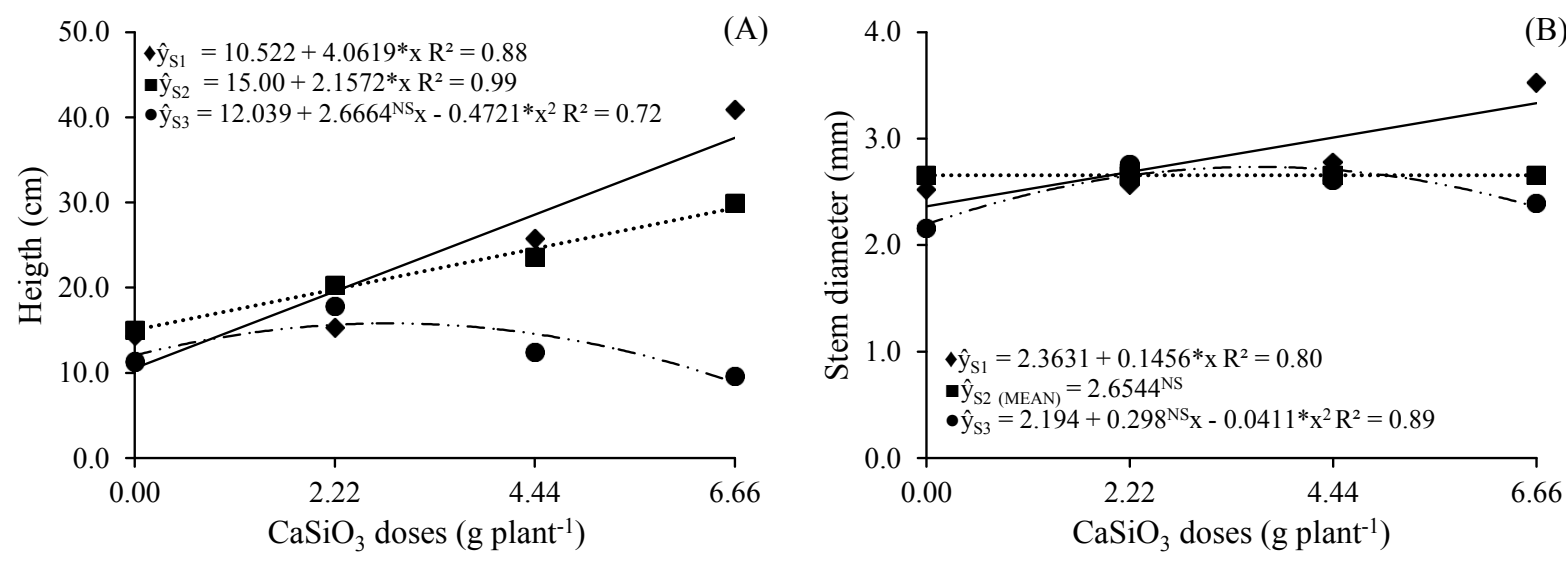

$*_{\text {and }}{ }^{\mathrm{NS}}=$ significant at $5 \%$ probability level and not significant, respectively. $\bullet_{\mathrm{S} 1}=0.5 \mathrm{dS} \mathrm{m}^{-1} ; \mathbf{m}_{\mathrm{S} 2}=1.7 \mathrm{dS} \mathrm{m}^{-1}$ and $\bullet \bullet_{\mathrm{S} 3}=$ $4.0 \mathrm{dS} \mathrm{m}^{-1}$.

Figure 1. Height (A) and stem diameter (B) of yellow passion fruit plants cv. BRS GA1 under saline water irrigation and calcium silicate doses.

The number of leaves of yellow passion fruit irrigated with waters of 0.5 and $1.7 \mathrm{dS} \mathrm{m}^{-1}$ responded linearly to the increase of calcium silicate doses, with increments of 28.37 and $19.25 \%$, respectively, when comparing plants fertilized with $\mathrm{CaSiO}_{3}$ doses
0.00 and $6.66 \mathrm{~g}$ of plant $^{-1}$, respectively (Figure 3A). For plants irrigated with $4.0 \mathrm{dS} \mathrm{m}^{-1}$ water, a quadratic behavior was observed, and the dose of $3.53 \mathrm{~g}$ promoted the highest number of leaves, 8.26 leaves per plant on average (Figure $2 \mathrm{~A}$ ).
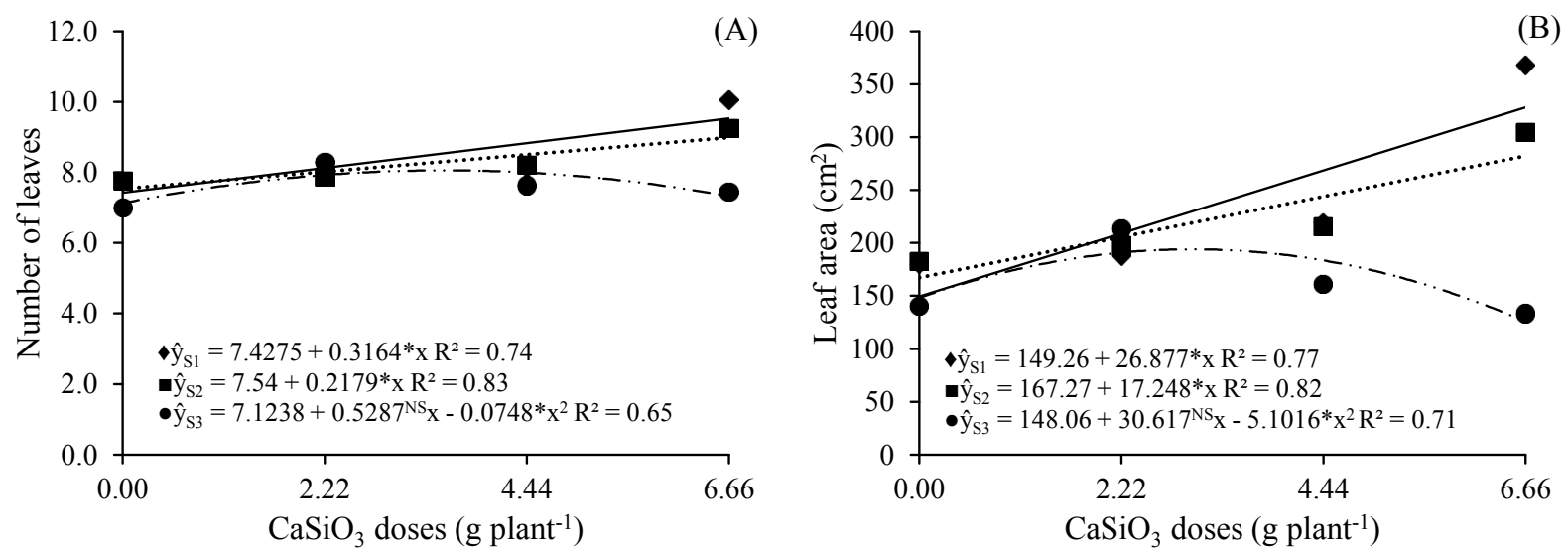

$*$ and ${ }^{\mathrm{NS}}=$ significant at $5 \%$ probability level and not significant, respectively. $\bullet_{\mathrm{S} 1}=0.5 \mathrm{dS} \mathrm{m} \mathrm{m}^{-1} ; \mathbf{\varpi}_{\mathrm{S} 2}=1.7 \mathrm{dS} \mathrm{m}^{-1}$ and $\bullet \bullet_{\mathrm{S} 3}=$ $4.0 \mathrm{dS} \mathrm{m}^{-1}$.

Figure 2. Number of leaves (A) and leaf area (B) of yellow passion fruit plants cv. BRS GA1 under saline water irrigation and calcium silicate doses.

The behavior of leaf area (Figure 2B) was similar to that found in the number of leaves. In seedlings irrigated with 0.5 and $1.7 \mathrm{dS} \mathrm{m}^{-1}$, respectively, leaf area was linearly as calcium silicate doses increased, with increments of 120.0 and $68.67 \%$ between the $\mathrm{CaSiO}_{3}$ doses of 0.00 and $6.66 \mathrm{~g} \mathrm{plant}^{-1}$. However, in seedlings irrigated with $4.0 \mathrm{dS} \mathrm{m}^{-1}$ water, LA was increased up to the $\mathrm{CaSiO}_{3}$ dose of $3.0 \mathrm{~g} \mathrm{plant}^{-1}$, reaching the maximum value of
$194.0 \mathrm{~cm}^{2}$ under conditions of high concentration of salts in irrigation water (Figure 2B).

Studies conducted by Moura et al. (2016), evaluating the effects of irrigation water salinity on the growth of different passion fruit species in the seedling phase [Passiflora gibertii, P. edulis Sims (cv. BRS GA1) and $P$. cincinnata], found that the growth of the yellow passion fruit cv. BRS GA1 was more affected by the irrigation water salinity from 
$2.14 \mathrm{dS} \mathrm{m}^{-1}$. In the genotypes BRS Sol do Cerrado and BRS Redondo Amarelo subjected to different levels of irrigation water electrical conductivity (ECw), Bezerra et al. (2016) observed that the high salinity of irrigation water reduces plant growth, and plant height and dry mass accumulation are the most affected variables.

In the initial development of two varieties of passion fruit (BRS Gigante Amarelo and BRS Rubi do Cerrado) irrigated with saline water, Andrade et al. (2018) observed that germination, growth and dry mass accumulation of the seedlings decrease with increasing water salinity, and salinity tolerance is different among yellow passion fruit varieties, with BRS GA1 considered more tolerant in the seedling phase.

The restriction on the growth of passion fruit plants as a function of the increase in salinity is related to the reduction in the osmotic potential of the substrate, caused by the accumulation of salts (SÁ et al., 2015). This fact compromises water absorption and, consequently, several metabolic processes, such as protein synthesis, lipid metabolism and photosynthesis, thus affecting cell division and elongation (GUPTA; HUANG, 2014; SÁ et al., 2017). These changes are responsible for the reductions in growth and reduction of leaf surface expansion, as observed in the studies of Bezerra et al. (2016), Moura et al. (2016) and Andrade et al. (2018), when evaluating the production of passion fruit seedlings irrigated with saline water.

In the present study, there were small restrictions caused by the effect of irrigation with saline water, even with irrigation water of $4.0 \mathrm{dS} \mathrm{m}^{-1}$ in the absence of fertilization with calcium silicate. This fact is related to the higher tolerance of the cv. BRS GA1 used in the present study, as reported by Moura et al. (2016) and Andrade et al. (2018). This tolerance was intensified with the application of calcium silicate, enabling the production of seedlings with adequate growth even under irrigation with $4.0 \mathrm{dS} \mathrm{m}^{-1}$ water, a salinity level pointed out by the authors mentioned above as extremely critical for the development of passion fruit.

Although $\mathrm{Si}$ is not considered an essential element, silicates, especially calcium and potassium silicates, optimize some physiological processes in plants, significantly increasing the yield of cultivated species, notably by the accumulation and polymerization of silicates in epidermal cells (GIONGO; BOHNEN, 2011; MATEOS-NARANJO; ANDRADES-MORENO; DAVY, 2013). According to Peixoto et al. (2011), this mechanism acts by forming a double layer of cuticle-silicon, which substantially reduces transpiration, improving water consumption and water use efficiency, thus improving tolerance to water scarcity, due to the osmotic effect caused by salinity. In addition, Si has physiological functions that increase antioxidant metabolism, reducing oxidative stress in plants (SHI et al., 2013).

Calcium, besides being an essential nutrient for plants, in the soil the ions compete for the charge sites with sodium, displacing it to the soil solution, facilitating its elimination by leaching fraction (SÁ et al., 2018).

The dry mass accumulation in the shoots of seedlings irrigated with 0.5 and $1.7 \mathrm{dS} \mathrm{m}^{-1}$ water increased linearly as calcium silicate doses increased, with increments of 36.6 and 58.2\%, between the lowest and highest doses of calcium silicate (Figure 3A). In yellow passion fruit seedlings irrigated with $4.0 \mathrm{dS} \mathrm{m}{ }^{-1}$ water, shoot dry mass accumulation showed a quadratic behavior, with the estimated maximum $\mathrm{CaSiO}_{3}$ dose of $3.29 \mathrm{~g} \mathrm{plant}^{-1}$, promoting SDM accumulation of $1.57 \mathrm{~g} \mathrm{plant}^{-1}$ (Figure 3A).

For dry mass accumulation in the roots, the data for yellow passion fruit seedlings irrigated with $0.5 \mathrm{dS} \mathrm{m}^{-1}$ water did not fit to any mathematical model with the increase $\mathrm{CaSiO}_{3}$ doses, with mean value of $0.794 \mathrm{~g} \mathrm{plant}^{-1}$ (Figure 3B). However, in seedlings irrigated with $1.7 \mathrm{dS} \mathrm{m}^{-1}$ water, there was a linear increase of $57.0 \%$ in the root dry mass accumulation, with the increase in calcium silicate doses between 0.00 and $6.66 \mathrm{~g} \mathrm{plant}^{-1}$, respectively (Figure 3B). In yellow passion fruit seedlings irrigated with $4.0 \mathrm{dS} \mathrm{m}^{-1}$ water, the behavior of root dry mass accumulation was quadratic, and the estimated maximum $\mathrm{CaSiO}_{3}$ dose of $3.78 \mathrm{~g}$ plant $^{-1}$ promoted the RDM accumulation of $0.71 \mathrm{~g} \mathrm{plant}^{-1}$ (Figure 3A).

The total dry mass of yellow passion fruit seedlings increased linearly, at a rate of $0.267 \mathrm{~g}$ per unit increment in calcium silicate doses, when irrigated with $0.5 \mathrm{dS} \mathrm{m}^{-1}$ water (Figure 3C). Similar behavior, but with lower intensity, was observed in plants irrigated with $1.7 \mathrm{dS} \mathrm{m}^{-1}$ water, and the unit increase of the silicate fertilizer led to an increment on the order of $0.178 \mathrm{~g}$ in TDM accumulation. When comparing the values of total dry mass of plants irrigated with water of 0.5 and $1.7 \mathrm{dS} \mathrm{m} \mathrm{m}^{-1}$, respectively, fertilized with the lowest and highest doses of silicon, there were increments of 92.0 and $64.7 \%$. In yellow passion fruit seedlings irrigated with $4.0 \mathrm{dS} \mathrm{m}^{-1}$ water, the behavior of total dry mass accumulation was quadratic, and the maximum estimated $\mathrm{CaSiO}_{3}$ dose of $3.48 \mathrm{~g}$ plant $^{-1}$ promoted TDM accumulation of $2.27 \mathrm{~g} \mathrm{plant}^{-1}$ (Figure 3A).

Reduction of biomass accumulation in yellow passion fruit seedlings irrigated with saline water has been observed by Oliveira et al. (2015), when evaluating the interaction between irrigation water salinity and substrates, as well as by Nascimento et al. (2017) and Souza et al. (2018), when evaluating the interaction between irrigation water salinity and organic fertilization with biofertilizers applied via soil in yellow passion fruit. The authors mentioned above observed drastic reductions in the biomass 
accumulation of seedlings irrigated using water with salinity greater than $2.0 \mathrm{dS} \mathrm{m}^{-1}$. The reductions in biomass accumulation were attributed to the accumulation of salts in the soil, causing their absorption and ionic effect, which causes toxicity by specific ions, especially $\mathrm{Cl}^{-}$and $\mathrm{Na}^{+}$ions. In addition, the accumulation of these ions in the soil causes nutritional imbalance due to the effect of ionic competition, of $\mathrm{Na}^{+}$with $\mathrm{K}^{+}, \mathrm{Ca}^{2+}$ and $\mathrm{Mg}^{2+}$, and of $\mathrm{Cl}^{-}$with $\mathrm{NO}_{3}^{-}, \mathrm{H}_{2} \mathrm{PO}_{4}^{-}$and $\mathrm{SO}_{4}^{-}$, affecting metabolic processes and biomass accumulation (SYVERTSEN; GARCIA-SANCHEZ, 2014; OLIVEIRA et al., 2015).

The use of calcium silicate mitigated the effects of salt stress on yellow passion fruit seedlings and increased biomass production when plants were irrigated with $4.0 \mathrm{dS} \mathrm{m}^{-1}$ water, a salinity level higher than the threshold $\left(2.1 \mathrm{dS} \mathrm{m}^{-1}\right)$ proposed in the literature for passion fruit seedlings (ARAÚJO et al., 2013). This result is attributed to the action of calcium silicate $\left(\mathrm{CaSiO}_{3}\right)$, as it reduces the absorption of toxic ions, such as sodium $\left(\mathrm{Na}^{+}\right)$, and promotes the increase in potassium $\left(\mathrm{K}^{+}\right)$uptake, and improvements in the integrity and stability of cell membrane, as well as in metabolic, physiological and structural activities of plants under abiotic stress (ASHRAF et al., 2010; SHEN et al., 2010; KAFI; RAHIMI, 2011; MATEOS-NARANJO; ANDRADES-MORENO; DAVY, 2013; NEVES et al., 2019).
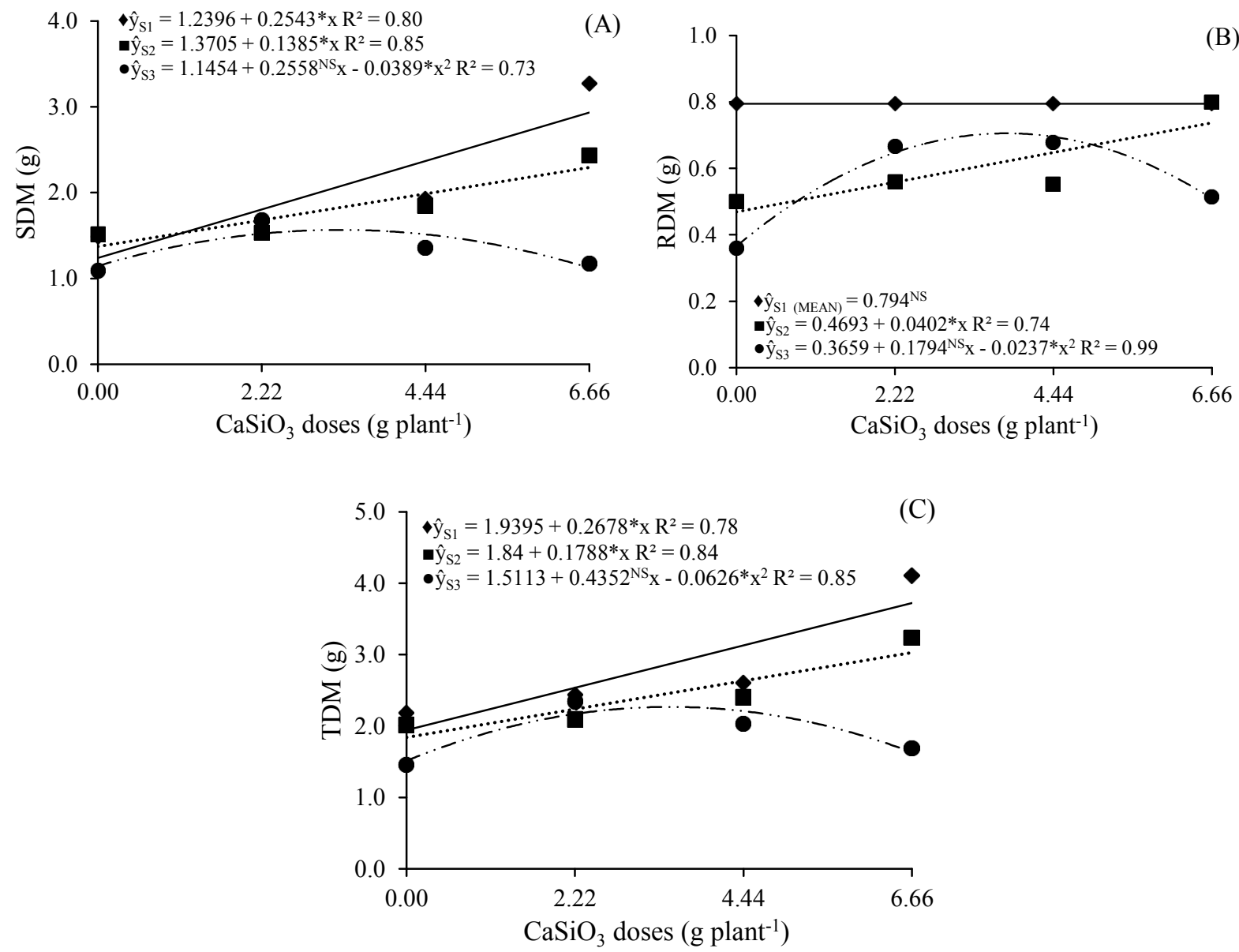

$*$ and ${ }^{\mathrm{NS}}=$ significant at $5 \%$ probability level and not significant, respectively. $\bullet_{\mathrm{S} 1}=0.5 \mathrm{dS} \mathrm{m}^{-1} ; \mathbf{m}_{\mathrm{S} 2}=1.7 \mathrm{dS} \mathrm{m}^{-1}$ and $\bullet_{\mathrm{S} 3}=$ $4.0 \mathrm{dS} \mathrm{m}^{-1}$.

Figure 3. Shoot dry mass (SDM), root dry mass (RDM) and total dry mass (TDM) of yellow passion fruit plants cv. BRS GA1 under saline water irrigation and calcium silicate doses. 


\section{CONCLUSIONS}

The use of saline well water of up to $1.7 \mathrm{dS} \mathrm{m}^{-1}$ does not have restriction for the production of seedlings of yellow passion fruit cv. BRS GA1.

The use of water with salinity of $4.0 \mathrm{dS} \mathrm{m}^{-1}$ restricted the initial development and biomass accumulation of passion fruit seedlings, and root dry mass was the most affected variable.

The application of calcium silicate at an average dose of $3.5 \mathrm{~g}$ per plant mitigates salt stress on the initial growth and biomass production of seedlings of yellow passion fruit cv. BRS GA1 irrigated with water of up to $4.0 \mathrm{dS} \mathrm{m}^{-1}$.

\section{REFERENCES}

ANDRADE, J. R. et al. Germination and morphophysiology of passion fruit seedlings under salt water irrigation. Pesquisa Agropecuária Tropical, 48: 229-236, 2018.

ARAÚJO, W. L. et al. Produção de mudas de maracujazeiro-amarelo irrigadas com água salina. Agropecuária Científica no Semiárido, 9: 15-19, 2013.

ASHRAF, M. et al. Alleviation of detrimental effects of $\mathrm{NaCl}$ by silicon nutrition in salt-sensitive and salttolerant genotypes of sugarcane (Saccharum officinarum L.). Plant and Soil, 326: 381-391, 2010.

AYERS, R. S.; WESTCOT, D. W. Water quality for agriculture. Rome: Food and Agriculture Organization of the United Nations, 1985. 174 p.

BEZERRA, J. D. et al. Crescimento de dois genótipos de maracujazeiro-amarelo sob condições de salinidade. Revista Ceres, 63: 502-508, 2016.

BEZERRA, M. A. F. et al. Nitrogen as a mitigator of salt stress in yellow passion fruit seedlings. Semina: Ciências Agrárias, 40: 611-622, 2019.

FERREIRA, D. F. Sisvar: a guide for its bootstrap procedures in multiple comparisons. Ciência e Agrotecnologia, 38: 109-112, 2014.

GIONGO, V.; BOHNEN, H. Relação entre alumínio e silício em genótipos de milho resistente e sensível a toxidez de alumínio. Bioscience Journal, 27: 348$356,2011$.

GUPTA, B.; HUANG. B. Mechanism of salinity tolerance in plants: physiological, biochemical, and molecular characterization. International Journal of Genomics, 2014: 1-18, 2014.
HOLANDA FILHO, R. S. F. et al. Água salina nos atributos químicos do solo e no estado nutricional da mandioqueira. Revista Brasileira de Engenharia Agrícola e Ambiental, 15: 60-66, 2011.

KAFI, M.; RAHIMI, Z. Effect of salinity and silicon on root characteristics, growth, waterstatus, propline contents and íon accumulation of purslane (Portulaca oleracea L.). Soil Science and Plant Nutrition, 57: 341-347, 2011.

MATEOS-NARANJO, E.; ANDRADESMORENO, L.; DAVY, A. J. Silicon alleviates deleterious effects of high salinity on the halophytic grass Spartina densiflora. Plant Physiology and Biochemistry, 63: 115-121, 2013.

MEDEIROS, J. F. et al. Caracterização das águas subterrâneas usadas para irrigação na área produtora de melão da Chapada do Apodi. Revista Brasileira Engenharia Agrícola e Ambiental, 7: 469-472, 2003.

MELETTI, L. M. M. Avanços na cultura do Maracujá no Brasil. Revista Brasileira de Fruticultura, 33: 83-91, 2011.

MOURA, R. S. et al. Tolerance of passion fruit species under salt stress. International Journal of Current Research, 8: 37689-37695, 2016.

NASCIMENTO, E. S. et al. Formação de mudas de maracujazeiro amarelo irrigadas com águas salinas e biofertilizantes de esterco bovino. Revista Agropecuária Técnica, 38: 1-8, 2017.

NEVES, J. M. G. et al. Silicon and boron mitigate the effects of water deficit on sunflower. Revista Brasileira de Engenharia Agrícola e Ambiental, 23: 175-182, 2019.

OLIVEIRA, F. A. et al. Interação salinidade da água de irrigação e substratos na produção de mudas de maracujazeiro amarelo. Comunicata Scientiae, 6: 471-478, 2015

PEIXOTO, M. L. et al. Efeito do silício na preferência para oviposição de Bemisia tabaci biotipo b (genn.) (hemiptera: aleyrodidae) em plantas de feijão (Phaseolus vulgaris L.). Ciência e Agrotecnologia, 35: 478-481, 2011.

RHOADES, J. D. et al. The use of saline waters for crop production. Rome: FAO (Irrigation and Drainage Paper, 48), 1992. 133 p.

SÁ, F. V. S. et al. Balanço de sais e crescimento inicial de mudas de pinheira (Annona squamosa 1.) sob substratos irrigados com água salina. Irriga, 20: 544-556, 2015. 
SÁ, F. V. S. et al. Correção de solo salino-sódico com condicionadores e doses de fósforo para cultivo do sorgo sacarino. Revista Brasileira de Agricultura Irrigada, 12: 2854-2865, 2018.

SÁ, F. V. S. et al. Tolerance of peanut (Arachis hypogea) genotypes to salt stress in the initial phase. Revista Brasileira de Engenharia Agrícola e Ambiental, 24: 37-43, 2020.

SÁ, F. V. S. et al. Water relations and gas exchanges of West Indian Cherry under salt stress and nitrogen and phosphorus doses. Journal of Agricultural Science, 9: 168-177, 2017.

SCHMILDT, E. R. et al. Equações para estimar área foliar de maracujá amarelo. Nucleus, 13: 97-104, 2016.

SHEN, X. et al. Silicon effects onphotosynthesis and antioxidant parameters of soybean seedlings under drought and ultraviolet-B radiation. Journal of Plant Physiology, 167: 1248-1252, 2010.

SHI, Y. et al. Silicon decreases chloride transport in rice (Oryza sativa L.) in saline conditions. Journal of Plant Physiology, 170: 847-853, 2013.

SILVA, A. A. R. et al. Gas exchanges and growth of passion fruit seedlings under salt stress and hydrogen peroxide. Pesquisa Agropecuária Tropical, 49: e55671, 2019.

SOUZA, J. T. A. et al. Effects of water salinity and organomineral fertilizationon leaf composition and production in Passiflora edulis. Revista Brasileira de Engenharia Agrícola e Ambiental, 22: 535-540, 2018.

SYVERTSEN， J. P.; GARCIA-SANCHEZ， F. Multiple abiotic stresses occurring with salinity stress in citrus. Environmental and Experimental Botany, 103: 128-137, 2014. 